\title{
PRIVATISASI BUMN DAN PENEGAKAN GOOD CORPORATE GOVERNANCE DAN KINERJA BUMN
}

\author{
Ilya Avianti \\ Universitas Padjadjaran
}

\begin{abstract}
Privatization of State Owned Companies (BUMN) represents government efforts in order to improve performance of such companies through ownership and transfer of control to other parties (private sectors). However, this privatization, in fact, has not yet been able to increase profitability and maintain good corporate governance. The efforts to create effectiveness and efficiency of such companies could be done by enhancing public ownership, enforcing corporate governance principles, and empowering role of audit committee and independent director/commissioner.

Keywords: Privatization, State Owned Companies, Corporate Governance Enforcement and Performance
\end{abstract}

\section{PENDAHULUAN}

Badan Usaha Milik Negara (BUMN) merupakan salah satu pelaku kegiatan ekonomi dalam perekonomian nasional yang berdasarkan demokrasi ekonomi (Undang-undang RI NO. 19, tentang BUMN, 2003). Oleh karena pengelolaannya berdasarkan demokrasi ekonomi, maka di dalam menjalankan aktivitas perekonomiannya perlu mengikuti mekanisme pasar dan berorientasi ke profit. Munculnya undang-undang BUMN No. 19 Tahun 2003 tersebut, karena peran BUMN dalam mewujudkan kesejahteraan masyarakat belum optimal, pengelolaan dan pengawasannya perlu dilakukan secara profesional dan pengelolaan BUMN perlu menyesuaikan dengan perkembangan perekonomian dan dunia usaha yang semakin pesat, baik secara nasional maupun internasional.

Berdasarkan data Masterplan BUMN 2002-2006, total aset dari 145 BUMN pada tahun 2001 sekitar Rp 800 triliun dengan perincian 13 BUMN memiliki pertumbuhan pendapatan lebih dari 18\% pertahun (kategori high sustainabe growth) dan memberikan kontribusi pendapatan sebesar 34 persen per tahun, 19 BUMN memiliki pertumbuhan 7-18 persen pertahun (kategori sustainabe growth) dan memberikan kontribusi pendapatan sebesar 13 persen, dan 103 BUMN memiliki pertumbuhan kurang dari 7 persen, kontribusi pendapatan yang diberikan hanya sebesar 8 persen. Sementara itu kinerja keuangan BUMN pada tahun 1996; 51,7 persen tergolong sehat dan sehat sekali, 27,5 persen tergolong tidak sehat. Pada tahun 1997, keuntungan yang dihasilkan dari modal pemerintah sebesar Rp 462 triliun hanya sebesar Rp11,8 triliun (Return on invesment/ROI $=2,55 \%$ ) dan memiliki ROA sebesar $4 \%$. ROI dan ROA yang rendah menunjukkan bahwa BUMN dalam menggunakan sumber daya ekonomisnya tidak efektif dan tidak efisien (Bastian, 2000).

Upaya pemerintah dalam rangka memperbaiki kinerja BUMN dilakukan antara lain melalui privatisasi BUMN. Tetapi privatisasi BUMN banyak menuai protes dari berbagai kalangan, sehingga timbul pertanyaan apakah privatisasi BUMN dapat mewujudkan penegakan Good corporate governance dan meningkatkan kinerja BUMN? 


\section{TINJAUAN LITERATUR}

\subsection{Privatisasi}

Menurut Ramamurti pengertian privatisasi dibedakan menjadi dua, pertama, privatisasi secara sempit adalah seluruh aktivitas yang ditujukan untuk mentransfer beberapa atau semua kepemilikan dan/atau kontrol pemerintah atas BUMN ke sektor swasta. Kedua, privatisasi secara luas adalah segala aktivitas pemerintah yang ditujukan untuk meningkatkan peranan swasta dalam perekonomian. Hal ini meliputi kebijakan tentang liberalisasi ekonomi dan perbaikan fungsi institusi swasta serta pasar dalam perekonomian (Firmanzah, 2003; 3). Adapun pengertian privatisasi menurut UU No. 19, Tahun 2003 Tentang BUMN, yaitu bahwa privatisasi adalah penjualan saham persero, baik sebagian maupun seluruhnya kepada pihak lain dalam rangka meningkatkan kinerja dan nilai perusahaan, memperbesar manfaat bagi negara dan masyarakat, serta memperluas kepemilikan saham oleh masyarakat. Privatisasi merupakan transformasi sistem ekonomi yang terpusat pada negara (State centered economic system) menjadi sistem ekonomi pasar bebas (Free market economic system). Dengan demikian, privatisasi dalam artikel ini mengacu pada pengertian privatisasi secara sempit dan sasaran privatisasi adalah BUMN persero. Motivasi banyak negara melakukan privatisasi adalah untuk memperbaiki kinerja BUMN akibat status kepemilikan BUMN dan masalah siapa yang bertanggungjawab atas kinerja BUMN tersebut, mengurangi monopoli, membangun mekanisme pasar dalam rangka memacu efisiensi usaha dan meningkatkan penerimaan negara, melalui berbagai cara mengurangi subsidi kepada BUMN dengan harapan dapat meningkatkan kontribusi negara atas dividen dan dalam jangka panjang dapat meningkatkan penerimaan pajak (Tanuhito, 2003).

Privatisasi BUMN menimbulkan pro-kontra di kalangân masyarakat. Berbagai pihak yang kontra beranggapan bahwa privatisasi merupakan sarana untuk menjual aset-aset negara untuk kepentingan kelompok-kelompok tertentu. Di sisi lain berbagai pihak yang pro beranggapan bahwa melalui privatisasi dapat meningkatkan kinerja BUMN. Anggapan bahwa privatisasi dapat meningkatkan kinerja BUMN didasarkan pada pemikiran bahwa melalui privatisasi hambatan birokrasi dapat dikurangi sehingga pengembilan keputusan manajerial dapat dilakukan relatif lebih cepat dan mengarah pada profitable, perusahaan lebih mampu merespon pasar dan meningkatkan daya saing dalam menghadapi persaingan bebas, meningkatkan kontribusi BUMN bagi perekonomian secara makro dan memaksimalkan kemakmuran Stakeholders (Wiryawan dan Wiryawan, 2003).

Privatisasi dapat dilakukan secara langsung, maupun melalui pasar modal. Privatisasi secara langsung dapat memberi peluang untuk menguasai saham mayoritas dan manajemen BUMN oleh investor. Mekanisme privatisasi melalui pasar modal, berarti publik dapat ikut memiliki saham suatu BUMN dan BUMN tersebut wajib mengikuti peraturan pasar modal. Dalam beberapa kasus privatisasi di beberapa negara, kadang privatisasi ditujukan kepada investor tertentu, misal investor asing, karena alasan dana, teknologi dan kemampuan manajerial. Tetapi hal tersebut dapat menimbulkan tuduhan bahwa pemerintah akan menjual aset nasional kepada pihak asing ( Sobel, 1993).

Kompleksitas privatisasi timbul karena privatisasi memiliki makna yang berbeda sesuai dengan prioritas dan konteksnya, privatisasi merupakan penguatan peran swasta dan pengurangan peran pemerintah di bidang perekonomian. Upaya untuk memasukkan semangat dan perilaku bisnis swasta ke dalam perusahaan negara merupakan bagian terpenting dalam privatisasi (Zaroni, 2004) dalam rangka meningkatkan keefektifan dan keefisienan badan usaha tersebut. Istilah privatisasi berkaitan erat dengan konsep Good corporate governance yang menjadi salah satu tujuan strategi atas pelaksanaan program privatisasi BUMN. Privatisasi mengarahkan BUMN memasuki persaingan pasar, produk dan membebaskan manajemen dari tekanan langsung pihak-pihak yang memiliki kepentingan tetap terhadap BUMN tersebut (Ramanadham, 1991). 
Privatisasi, Penegakan Good Corporate Governance, dan Kinerja BUMN (Ilya Avianti)

Proses privatisasi perlu dilakukan secara transparan utuk kepentingan akuntabilitas pemerintah kepada negara dan bangsa, dan proses tersebut perlu disosialisasikan dengan intensif agar dipahami dengan baik oleh para stakeholder bahwa privatisasi dilaksanakan untuk kepentingan bangsa serta merupakan jalan terakhir setelah upaya lain dilakukan (Wiryawan dan Wiryawan, 2003).

\subsection{Good Corporate Governance.}

Issue tentang Corporate governance muncul ketika krisis ekonomi melanda negara-negara Asia, khususnya Asia tenggara termasuk Indonesia. Namun demikian Good corporate governance merupakan istilah yang muncul dari interaksi di antara manajemen, pemegang saham, dewan direktur dan pihak terkait lainnya, akibat terjadinya inkonsistensi antara "apa" dan apa yang seharusnya" (Tricker, 1991). Hal itu berarti Good corporate governance bersifat normatif.

Ada beberapa pengertian tentang tentang Good corporate governance (GCG), antara lain:

Menurut Organization for Economic Cooperation and Development (OECD) ada dua konteks definisi GCG; pertama, merupakan hubungan dan pla perilaku yang berbeda yang berkaitan dengan kewajiban para manajer, pemegang saham, karyawan, kreditur, pelanggan kunci, serta masarakat, untuk membentuk strategi perusahaan. Konteks tersebut disebut sebagai sisi keperilakuan tata kelola perusahaan (behavioural side of corporate governance), kedua, tata kelola perusahaan berkaitan dengan seperangkat peraturan tentang kerangka hubungan dan perilaku perusahaan swasta, kemudian membentuk perumusan strategi perusahaan, hal ini dapat berupa hukum perusahaan, peraturan sekuritas dan persyaratan listing, tetapi dapat juga menjadi peraturan yang disusun oleh perusahaan itu sendiri. Hal ini dapat disebut sebagai sisi normatif dari tata kelola perusahaan (normative side of corporate governance) (Nestor, 2001).

Menurut The Indonesian institute for corporate governance (IICG); suatu proses dan struktur ang diterapkan dalam menjalankan perusahaan dengan tujuan utama meningkatkan nilai pemegang saham dalam jangka panjang, dengan tetap memperhatikan kepentingan stakeholders yang lain (FCGI, 2001)

Keputusan Menteri BUMN No. KEP-117/M-BUMN/2002, Pasal 1, butir a; suatu proses dan struktur yang digunakan oleh organ BUMN untuk meningkatkan keberhasilan usaha dan akuntabilitas perusahaan guna mewujudkan nilai pemegang saham dalam jangka panajang dengan tetap memperhatikan kepentingan stakeholder lainnya, berlandaskan peraturan perundangan dan nilainilai etika.

Corporate governance dapat ditinjau dari proses maupun pengendalian (Syahroza, 2005). Corporate governance ditinjau dari sisis proses menyangkut penegakan atas prinsip-prinsipnya yang terdiri atas transparansi, kemandirian, akuntabilitas, pertanggungjawaban, dan kewajaran (Menteri BUMN No. KEP-117/M-BUMN/2002). Sementara itu Corporate governance dari sisi pengendalian dapat dilihat dari kepemilikan institusional, kepemilikan manajerial, peran komite audit dan komisaris independen (Fama dan Jensen, 1983). Kepemilikan institusional atas saham BUMN, mengakibatkan ada pihak eksternal secara kelembagaan ikut berperan dalam dalam pengambilan keputusan dan pengendalian perusahaan. Sementara itu kepemilikan manajerial yang didasarkan pada bonus plan untuk manajer, akan dapat mengurangi konflik kepentingan antara manajer (agent) dengan principal.

Fungsi komite audit dalam membantu dewan komisaris, yaitu meningkatkan kualitas laporan keuangan, menciptakan iklim disiplin dan pengendalian yang dapat mengurangi kesempatan terjadinya penyimpangan dalam pengelolaan perusahaaan dan meningkatkan fungsi audit internal maupun audit eksternal, dan mengidentifikasi hal-hal yang memerlukan perhatian dewan komisaris (Herwidayatmo, 2002). Jumlah komite audit sekurang-kurangnya 3 orang dan salah satunya dari komisaris independen dan merangkap sebagai ketua. Sementara itu komisaris independen berfungsi menyelaraskan kepentingan para pemegang saham dalam rangka melindungi hak-hak pemegang saham minoritas. Ketentuan peraturan BEJ mengharuskan 
perusahaan yang terdaftar di BEJ memiliki jumlah komisaris independen yang jumlahnya proporsional dengan jumlah saham yang dimiliki oleh bukan pemegang saham pengendali atau minimal 30\%. Sementara itu menurut ketentuan Menteri BUMN paling sedikit 20\% anggota komisaris berasal dari kalangan di luar BUMN dan bagi BUMN persero diupayakan agar pendapat pemegang saham minoritas diperhatikan sebagai wujud perlindungan terhadap kepentingan pemegang saham minoritas dan stakeholders.

Penegakan prinsip-prinsip corporate governance yang didukung oleh mekanisme corporate governance menanggulangi terjadinya informasi yang tidak simetris. Berarti penegakan Good corporate governance dapat membantu BUMN yang diprivatisasi menyajikan informasi akuntansi sesuai dengan kondisi yang sesungguhnya terjadi. Sehingga informasi akuntansi tersebut dapat dijadikan sebagai salah satu dasar dalam pengambilan keputusan bisnis bagi berbagai pihak yang terkait.

\subsection{Kinerja Keuangan BUMN}

Kinerja keuangan merupakan hasil (outcome) yang diperoleh dari suatu aktivitas usaha. Untuk mengetahui kinerja keuangan perusahaan baik atau buruk, perlu dilakukan pengukuran terhadap kinerja keuangan tersebut. Kinerja keuangan secara umum mengukur keefektifan dan keefisienan (Horngren, Foster dan Datar, 2000). Demikian pula menurut Hitt (1995) bahwa nilai utama yang akan dihasilkan dari evaluasi terhadap kinerja keuangan perusahaan adalah efektif dan efisien. Pengukuran kinerja keuangan menyediakan indikator-indikator untuk mengetahui bagaimana menjalankan suatu organisasi secara baik (Jusoh, 2000).

Indikator yang digunakan untuk menilai kinerja BUMN adalah Kep.Men BUMN No. Kep100/MBU/2002, yaitu keputusan Menteri BUMN untuk menilai tingkat kesehatan BUMN, yang digolongkan menjadi sehat (A s/d AAA), kurang Sehat (B s/d BBB) dan tidak sehat ( $\mathrm{s} / \mathrm{d}$ CCC). Pengukuran tingkat kesehatan BUMN mencakup aspek keuangan, aspek operasional dan aspek administrasi. Aspek keuangan terlebih dahulu diukur dengan rasio keuangan. Jika dikaitkan dengan Corporate governance, maka Corporate governance merupakan penggerak kinerja (performance driven) (Millstein, Albert dan Cadbury et al., 1998; Keasey, Thompson dan Wright, 1997; 5). Berarti penegakan Corporate Governance dapat mendorong kinerja perusahaan.

\section{PEMBAHASAN}

\subsection{Apakah Privatisasi BUMN Dapat Mewujudkan Penegakan Good Corporate Governance?}

Mayoritas BUMN termasuk kategori Low growth dengan pertumbuhan pendapatan kurang dari $7 \%$ per tahun dan hanya memberi kontribusi pendapatan 8 persen, sementara itu angsuran hutang negara beserta bunga angsuran yang relatif besar, belanja rutin dan pembangunan yang memerlukan dana relatif besar, mengakibatkan perlunya privatisasi BUMN.

Tujuan Privatisasi BUMN sebagaimana dalam undang-undang No.19, 2003 untuk meningkatkan kinerja dan nilai tambah perusahaan, serta meningkatkan peran serta masyarakat dalam pemilikan saham persero. Privatisasi BUMN dilakukan dengan memperhatikan prinsipprinsip transparansi, kemandirian, akuntabilitas, pertanggungjawaban dan kewajaran (UU No. 19, Pasal 75,2003 ). Dengan demikian privatisasi BUMN seharusnya dapat mewujudkan penegakan tata kelola perusahaan yang baik.

Kenyataan yang ada bahwa kemadirian BUMN masih relatif sulit diwujudkan, kekuasaankekuasaan tertentu masih mewarnai pengambilan keputusan BUMN yang diprivatisasi, dibandingkan dengan keputusan ekonomis yang profitable. Dengan demikian secara umum BUMN yang diprivatisasi belum dapat mewujudkan prinsip kemandirian. Secara substansi, BUMN yang diprvatisasi belum menyentuh struktur dan mekanisme Good governance (Akhmad Syakhroza, 2005), sehingga efisiensi, profesionalisme dan berdaya saing, belum dapat diwujudkan.

Struktur governance terkait dengan struktur organ perseroan terbatas di Indonesia mengacu pada Undang-undang perseroan terbatas Tahun 1995 pasal 80, ayat 1 dan pasal 91 ayat 
1; yaitu bahwa anggota direksi diangkat dan diberhentikan oleh RUPS, demikian pula dengan komisaris diangkat dan diberhentikan oleh RUPS sebagaimana pasal 95 ayat 1 dan 101 ayat 1. Dengan demikian baik dewan direksi maupun dewan komisaris bertanggungjawab secara langsung kepada RUPS. Jika dibandingan dengan struktur organ perseroan terbatas menurut model continental (Two-tier board) dan model anglo-saxon (One-tier board), maka peran dewan komisaris dalam menjalan fungsi pengendalian, tidak sekuat sebagaimana model Anglo-saxon dan Continental.

BUMN yang diprivatisasi adalah yang berbentuk perseoran terbatas. Jika struktur organ perseroan terbatas tersebut mengacu pada UU No.1 tahun 1995, maka dewan komisaris pada BUMN yang diprivatisasi tersebut tidak memiliki peran pengendalian sekuat model continental maupun anglo-saxon.

Maksud dilakukannya privatisasi BUMN antara lain untuk memperluas kepemilikan masyarakat atas persero dan menciptakan struktur keuangan yang kuat/baik (UU BUMN No 19, pasal 74, 2003). Struktur keuangan yang kuat dapat pula ditinjau dari struktur kepemilikan, proporsi kepemilikan yang lebih besar dari proporsi hutang, akan mengakibatkan rasio hutang atas ekuitas (Debt to equity ratio) menjadi relatif rendah. Perusahaan yang memiliki rasio hutang atas ekuitas relatif rendah, struktur permodalannya relatif baik. Adapun perluasan kepemilikan masyarakat, merupakan strategi pendanaan tidak melalui hutang, tetapi melaui transfer kepemilikan kepada masyarakat. Transfer kepemilikan tersebut akan mengurangi dominasi kepemilikan pemerintah, akibat adanya kepemilikan masyarakat ada pengendali perusahaan selain pemerintah dan manajemen BUMN, sehingga diharapkan privatisasi BUMN dapat menciptakan efisiensi dan berdaya saing. Namun demikian, realita yang ada bahwa kepemilikan publik terhadap privatisasi BUMN di pasar modal masih relatif sedikit dengan rata-rata kepemilikan publik 23,96 persen. Hal tersebut dapat ditunjukkan oleh tabel.1 di bawah.

Tabel.1.

Komposisi Kepemilikan

\begin{tabular}{llcccc}
\hline No & \multicolumn{2}{c}{ Nama BUMN } & Kepemilikan & Lain-lain \\
\hline 1. & PT. Semen Gersik Tbk & $51.01 \%$ & $23.46 \%$ & $25.53 \%$ & Cemex \\
2. & PT. Indosat Tbk & $65.00 \%$ & $35.00 \%$ & & \\
3. & PT. Timah Tbk & $65.00 \%$ & $35.00 \%$ & & \\
4. & PT. Telkom Tbk & $54.29 \%$ & $11.05 \%$ & $34.66 \%$ & Asing \\
5. & PT. Aneka Tambang Tbk & $65.00 \%$ & $35.00 \%$ & & \\
6. & PT. Indofarma & $80.73 \%$ & $19.27 \%$ & & \\
7. & PT. Kimia Farma & $90.03 \%$ & $9.00 \%$ & $0.07 \%$ & Karyawan \\
\multicolumn{7}{c}{ Rata-Rata } & $67,29 \%$ & $23.96 \%$ & & \\
\hline
\end{tabular}

Sumber: Capital Market Directory, 2002

Struktur kepemilikan akan terkait dengan mekanisme Corporate governance. Struktur kepemilikan dapat berupa kepemilikan institusional dan kepemilikan manajerial. Peningkatan kepemilikan institusional dapat mengimbangi kebutuhan terhadap hutang dan kepemilikan manajerial untuk mengurangi biaya keagenan (Bathala et al., 1994). Penelitian Ugurlu (2000) membuktikan bahwa hubungan antara mekanisme pengendalian digunakan untuk menyelaraskan kepentingan manajer dengan pemegang saham. Sementara itu hasil penelitian Fama dan Jensen (1983) Menunjukkan bahwa mekanisme tata kelola perusahaan menekankan dari aspek pengendalian (1983). 
Mekanisme tata kelola diarahkan untuk menjamin dan mengawasi pelaksanaan sistem tata kelola dalam suatu perusahaan. Mekanisme tata kelola perusahaan terdiri atas mekanisme internal meliputi kepemilikan manajerial, struktur dewan direksi, kompensasi eksekutif, dan mekanisme eksternal meliputi mekanisme pasar, kepemilikan istitusional dan pinjaman dari debtholder. Untuk menjelaskan mekanisme corporate governance yang berperan dalam pengendalian perusahaan sebagaimana penelitian Fama dan Jensen,maka mekanisme tersebut dalam artikel ini meliputi struktur kepemilikan, struktur dewan komisaris dan komite audit.

Disamping sebagai pengimbang kebutuhan akan hutang, kepemilikan institusional dapat pula berperan dalam pengambilan keputusan bisnis dan dalam pengendalian perusahaan. Namun demikian, kepemilikan institusional dapat menjadi sasaran empuk untuk menuai protes terhadap BUMN yang diprivatisasi, karena dapat saja menimbulkan dugaan sebagai saran penjualan aset negara kepada pihak-pihak tertentu. Untuk mengatasi hal tersebut UU No 19 tahun 2003 telah memberikan rambu-rabu pada pasal 76 butir 1 (a) dan (b), yaitu bahwa kriteria BUMN yang diprvatisasi, merupakan industri atau sektor usaha yang kompetitif dan yang unsur teknologinya cepat berubah. Adapun pasal 77 menjelaskan BUMN yang tidak dapat diprivatisasi, yaitu pesero yang hanya boleh dikelola oleh BUMN, sektor usahanya berkaitan dengan pertahanan dan keamanan, bergerak di bidang tertentu yang khusus untuk melaksanan kegiatan yang berkaitan dengan kepentingan masyarakat dan yang bergerak di bidang sumber daya alam.

Kepemilikan manajerial menurut Ugurlu untuk menselaraskan kepentingan manajemen dan pemilik, sehingga dapat meminimalkan biaya keagenan. Adapun komite audit sebagai salah satu unsur mekanisme corporate governance berperan meningkatkan kualitas laporan keuangan, mengurangi kesempatan terjadinya penyimpangan dalam pengelolaan perusahaaan, meningkatkan fungsi audit internal maupun audit eksternal, dan mengidentifikasi hal-hal yang memerlukan perhatian dewan komisaris. Jika peran komite audit dikaitkan dengan Keputusan Menteri BUMN No.103/MBU/2002, pasal 4, yaitu bahwa komposisi keanggotaan komite audit terdiri atas (a) satu orang anggota komisaris, (b) dua orang dari luar BUMN yang bertindak sebagai ketua adalah anggota komisaris sebagaimana butir (a) tersebut. Jika keanggotaan komite audit dikaitkan dengan UU No.19, 2003, pasal 74 butir 1(a); maksud pelaksanaan privatisasi untuk memperluas kepemilikan masyarakat atas persero. Seharusnya unsur dan ketua komite audit berasal dari komisaris independen dan jumlah komisaris independen harus proporsional dengan kepemilikan masyarakat atau publik. Demikian pula jumlah komisaris independen minimal $30 \%$ dari anggota komisari sebagaimana peraturan pasar modal Indonesia. Keanggotaan komite audit sebagaimana Kep. Men 103/2003, akan menghambat penegakan salah satu prinsip-prinsip corporate governance, yaitu keadilan (Fairness). Dengan kondisi yang demikian, maka privatisasi BUMN belum mampu mewujudkan penegakan Good corporate Governance.

\subsection{Apakah Privatisasi BUMN Dapat Meningkatkan Kinerja Keuangan?}

Privatisasi BUMN, secara umum belum mampu Good corporate governance. Sementara itu sebagaimana dalam kajian teori disebutkan bahwa Corporate governance merupakan penggerak kinerja. Ternyata bahwa BUMN yang diprivatisasi di pasar modal, memiliki rata-rata kemampulabaan yang relatif rendah, kecuali PT Telkom, tbk. Kemampulabaan BUMN yang diprivatisasi sebagaimana Tabel 2 di bawah. 
Privatisasi, Penegakan Good Corporate Governance, dan Kinerja BUMN (Ilya Avianti)

Tabel 2

Kemampulabaan BUMN yang diprivatisasi di Pasar Modal

\begin{tabular}{llcc}
\hline No & \multicolumn{1}{c}{ Nama BUMN } & ROE (\%) & ROI (\%) \\
\hline 1. & PT. Semen Gersik Tbk & 8,22 & 3,87 \\
2. & PT. Indosat Tbk & 3,17 & 1,53 \\
3. & PT. Timah Tbk & 0,76 & 0,58 \\
4. & PT. Telkom Tbk & 52,49 & 19,72 \\
5. & PT. Aneka Tambang Tbk & 10,42 & 8,12 \\
6. & PT. Indofarma & $-15,32$ & $-7,39$ \\
7. & PT. Kimia Farma & 5,23 & 3,41 \\
\multicolumn{2}{c}{ Rata-Rata } & 9,28 & 4,26 \\
\hline
\end{tabular}

Sumber: Capital Market Directory,2002

Kemampulabaan BUMN yang diprivatisasi diukur dengan pendekatan rasio laba atas ekuitas (Return on equity/ROE) dan rasio laba atas investasi (Return on investmen/ROI) sebagaimana Tabel 2. Tetapi jika merujuk pada Keputusan Menteri BUMN No:Kep-100/MBU/2002, tingkat kesehatan BUMN ditinjau dari aspek keuangan, aspek operasional dan aspek administrasi. Peringkat kesehatan meliputi sehat (A - AAA), kurang sehat $(B-B B B)$ dan tidak sehat $(C-C C C)$. Jika tingkat kesehatan BUMN yang mencerminkan kinerja, hanya dilihat dari ROE dan ROI dan dikaitkan dengan Kepmen tersebut, maka Skor ROE yang memenuhi kriteria sehat atau berkinerja baik berkisar antara 8 sampai dengan 15 persen, sementara itu untuk ROI berkisar berkisar antara 10 sampai dengan 18 persen. Rata-rata ROE masih memenuhi kriteria sehat, namun demikian terpenuhinya kriteria sehat tersebut akibat salah satu BUMN yang diprivatisasi (lihat Tabel 2) memiliki ROE yang relatif tinggi, jadi sebenarnya ROE BUMN yang diprivatisasi secara umum relatif kurang baik, demikian pula dengan ROInya.

Kinerja keuangan secara umum mengukur keefektifan dan kefisienan pengelolaan suatu badan usaha (Horngeren, Foster dan Datar, 2000 dan Hitt, 1995). Skor ROE dan ROI BUMN yang diprivatisasi di pasar modal di bawah rata-rata industri, berarti BUMN tersebut belum efektif dan efisien, sehingga privatisasi BUMN belum mampu meningkatkan kinerjanya.

\section{SIMPULAN}

Privatisasi BUMN dapat diartikan sebagai transfer kepemilikan atau pengendalian pemerintah ke sektor swasta. Ada beberapa hal yang mendorong dilakukannya privatisasi, yaitu untuk memperbaiki kinerja BUMN akibat status kepemilikan BUMN dan masalah siapa yang bertanggungjawab atas kinerja BUMN tersebut, membangun mekanisme pasar dalam rangka memacu efisiensi usaha dan meningkatkan penerimaan negara, melalui berbagai cara mengurangi subsidi kepada BUMN dengan harapan dapat meningkatkan kontribusi negara atas dividen dan dalam jangka panjang dapat meningkatkan penerimaan pajak.

Tujuan privatisasi BUMN sebagaimana Undang-undang No. 19, 2003 untuk meningkatkan kinerja dan nilai tambah perusahaan, serta meningkatkan peran serta masyarakat dalam pemilikan saham persero. Namun demikian, dalam kenyataannya privatisasi BUMN secara rata-rata belum mampu mewujudkan pengelolaan badan usaha secara efektif dan efisien dan kepemilikan publikpun masih relatif rendah. Dominasi kepemilikan pemerintah pada BUMN persero dapat mengganggu penegakan prinsip-prinsip Good corporate governance dan dominasi kepemilik pemerintah dapat mengakibatkan pengambilan keputusan bisnis tidak profitable. Upaya yang perlu dilakukan dalam rangka mewujudkan tujuan privatisasi terkait dengan kinerja BUMN antara lain 
adalah menegakan prinsip-prinsip tata kelola perusahaan yang baik, dan memberdayakan peran komite audit dan komisaris independen.

\section{DAFTAR PUSTAKA}

Syahroza, A., (2005), Corporate Governance: Sejarah dan Perkembangan, Teori, Model dan Sistem Governance serta Aplikasinya pada Perusahaan BUMN, Jakarta: Fakultas Ekonomi Univessitas Indonesia.

Bathala T. C., Moon K. P., Rao R. P., (1994), "Managerial Ownership, Debt Policy and The Impact of Institutional Holdings: An Agency Perspective", Journal of Financial Management Association, Vol. 23 No.3.

Fama, E. F., Jensen, Michael C., (1983), "Agency Problems and Residual Claims", The Journal of Law and Economic, 26 (2).

Firmanzah, (2003), "Perubahan Organisasi dalam Post-privatisasi", Usahawan, No.5 Th XXXII,

Herwidayatmo, (2002), "Implementasi Good Corporate Governance untuk Perusahaan Publik Indonesia", The Essence of Good Corporate Governance, Konsep dan Implementasi Perusahaan Publik dan Korporasi Indonesia, Jakarta: Yayasan Pendidikan Pasar Modal Indonesia \& Sinergy Communication.

Hinuri, H., (2002), The Essence of Good Corporate Governance, Jakarta: Yayasan Pendidikan Pasar Modal Indonesia \& Sinergy Communication.

Horngren, Charles T, Srikant M. Datar, George Foster, (2003). Cost Accounting; Amanagerial Emphasisi, New Jersey: Pearson Education International.

Hitt, William.D, (1995), "The Learning Organization: Some Reflections on Organizational Renewal", Leadership and Organization Development Journal, Vol.16 (8).

Bastian, I., (2000), Privatisasi di Indonesia: Teori dan Implementasi, Pusat Pengembangan Akuntansi Fakultas Ekonomi Universitas Gajah Mada, Jakarta: Salemba Empat.

Tanuhito, J., (2003), "Privatisasi Bank Harus Didukung Serentetan Komitmen", Bisnis indonesia, 17 September.

Ruzita, J., (2000), "Performance Measurement in Manufacturing Sectors", The Malaysian Accountant.

Keasey, Kevin, Steve Thompson, dan Mike Wright, (1997), Introduction: The Corporate governance Problem-Competing Diagnoses and Solutions, Corporate Governance: Economic and Financial Issues, New York: Oxford University Press.

Menteri BUMN, Keputusan Menteri BUMN Nomor: KEP-100/MBU/2002, Tentang Penilaian Tingkat Kesehatan Badan Usaha Milik Negara.

Menteri BUMN, Keputusan Menteri BUMN Nomor: KEP-103/MBU/2002, Tentang Pembentukan Komite Audit bagi BUMN. 
Milstein, Ira M, Michel Albert, Sir Adrian Cadbury, Robert E. Denham, Dieter Feddersen dan Nobouo Tateisi, (1998), Coporate Governance; Improving Competitiveness and Access to Capital in Global Markets, Report to The OECD by Business Sector Advisory Group on Corporate Governance, France.

Wiryawan, N.J., dan Wiryawan, Z.Z., (2003), "Program Privatisasi di Indonesia Dilihat dari Pengalaman Privatisasi di Beberapa Negara Lain", Usahawan, No.3 Th XXXII.

Presiden Republik Indonesia, Undang-undang Nomor 1 Tahun 1995, Tentang Perseroan Terbatas

Presiden Republik Indonesia, Undang-undang Nomor 19 Tahun 2003, Tentang Badan Usaha Milik Negara.

Ramanadham, V.V, (1993), Privatization: AGlobal Prespective, London, UK: Routledge,

Sobel, V, (1993), Privatization in Central and Eastern Europe, In European Trends.

Tricker, (1994), International Corporate Governance, New Jersey: Prentice Hall, Inc,

Ugurlu, M., (2000), "Agency Cost and Corporate Control Device in The Turkish Manufacturing Industry", Journal of Economic Study, Vol. 27, No.6.

Zaroni, (2004), "Pengaruh Kepemilikan Pemerintah, Kepemilikan Asing, Pergantian CEO terhadap Kinerja Keuangan BUMN Sesudah diprivatisasi", Simposium Nasional Akuntansi.

Zhuang, Juzhong, David Edwards dan Ma.Virginita A. Capulong, (2001), "Corporate Governance and Finance in East Asia", A Study of Indonesia, Republic of Korea, Malaysia, Philippine, and Thailand, Volume Two, Country Studies; Asian Development Bank, 